\title{
Morphophysiological and agronomic performance of 42 common bean genotypes grown hydroponically under phosphorus deficiency
}

D.A. Silva, J.G.R. Gonçalves, T. Ribeiro, A.F. Chiorato and

S.A.M. Carbonell

Instituto Agronômico, Centro para Grãos e Fibras, Campinas, SP, Brasil

Corresponding author: D.A. da Silva

E-mail: daiagrouel2002@hotmail.com

Genet. Mol. Res. 20 (2): gmr18753

Received October 14, 2020

Accepted April 16, 2020

Published April 30, 2021

DOI http://dx.doi.org/10.4238/gmr18753

\begin{abstract}
An inadequate supply of phosphorus $(\mathrm{P})$ is one of the most limiting factors for plant nutrition, resulting in morphophysiological adjustments and reduced production. We evaluated 42 common bean germplasm bank accesses of the Instituto Agronômico Brazil that are divergent in root traits, using a hydroponic system to determine their performance under $\mathrm{P}$ deficiency. The plants were grown with a low $\mathrm{P}$ concentration $\left(4.00 \mathrm{mg} \mathrm{L}^{-1}\right)$ in a completely randomized experimental design, with three replications. Evaluations for shoot, root system and grain production traits were carried out, followed by individual analyses of variance, Scott-Knott mean test, Pearson correlation, and GGE-biplot analysis. Leaf chemical analysis showed a mean content of $2.20 \mathrm{~g} \mathrm{~kg}^{-1}$ of $\mathrm{P}$, a value below the recommended range, as expected. Analyses of variance showed a significant effect on most of the traits evaluated; the coefficients ranged from 7.1 to $19.8 \%$. The genotypes were clustered for most of the variables based on the ScottKnott mean test. Two genotypes (G 2333 and Rubi) stood out as the highest yielding, with a greater relative chlorophyll index and better development of the root system. A significant correlation was found between the the root traits length, surface area, and volume with production components. Based on GGE-biplot analysis, 12 genotypes were selected that simultaneously performed better for grain yield and root system.
\end{abstract}

Key words: Phaseolus vulgaris; Root system; P deficiency; GGE-biplot; Correlation 


\section{INTRODUCTION}

The common bean (Phaseolus vulgaris) is considered a nutrient-demanding crop; one of the most significant reasons for the low yields of this crop in Brazil is the low fertility of tropical soils. Among the contributing factors to this limitation is low phosphorus (P) availability (Silva and Vahl, 2002).

Responses such as low performance, morphophysiological adjustments, reduction in dry matter, and reduction in leaf area are associated with an inadequate supply of $\mathrm{P}$ to plants (Ericsson and Ingestad, 1988). Various strategies of adaptation to soil P deficiency have been developed by plants, involving diverse mechanisms of uptake, use, and remobilization of phosphate (Vance et al., 2003; Hammond et al., 2004; Lambers et al., 2006). Severe deficiencies in P limit plant development, including root development and architecture (Niu et al., 2013). Oliveira et al. (2014), studying the impact of phosphorous nutrition on plant growth, nitrogen fixation and ammonium assimilation in the common bean, found that $\mathrm{P}$ application increased leaf area, whole plant, nodule biomass and, shoot and root $\mathrm{P}$ content, while root growth was less sensitive to P deficiency than was shoot growth. They also showed that nitrogen fixation requires more $\mathrm{P}$ than does plant growth.

The length of the root system is considered an important trait of tolerance to $\mathrm{P}$ deficiency, and can be shown by the increase in nutrient uptake efficiency per root unit (Wissuwa, 2003). Beebe et al. (1995), Singh et al. (2003), Liao et al. (2004), and Henry et al. (2010) performed evaluations in soils with low $\mathrm{P}$ content and found germplasms tolerant to this deficiency, variability in root architecture and production, and divergent lines regarding P uptake efficiency, demonstrating opportunities for development and selection of improved varieties.

In plant breeding for the identification of cultivars that are efficient in the uptake and use of P, it is necessary to establish methods that are fast and of low cost and that allow discrimination of germplasms with high repeatability of the results and evaluation of a large number of plants, families, or populations (Fidelis et al., 2010). Thus, a study in a nutrient solution is advantageous in the sense of being able to control the growth conditions of the plants, examine the development of the root system, and compare a relatively large number of genotypes in a short time. Thus, characterization of accessions under stress conditions for identification of genotypes with greater root development and better P nutrient uptake constitutes an important step for evaluation of resources conserved in germplasm banks.

We examined the morphophysiological and agronomical responses of 42 common bean accesses from the active germplasm bank of Instituto Agronômico in Brazil regarding their performance in terms of shoot, root system and production components traits under low phosphorus concentration in a hydroponic system.

\section{MATERIAL AND METHODS}

We used 40 common bean genotypes from the Common Bean Germplasm Bank of the Instituto Agronômico (Table 1) that had been selected for being more divergent in a comparison of accessions, analyzing the number of whorls and basal roots and classified regarding the root system under water deficit (Teixeira et al., 2019), and two controls (G 2333, used as a standard of Efficient and Responsive, and DOR 364, used as a standard of Inefficient and Non-responsive), according to Silva et al. (2014). 
Table 1. Common bean genotypes used for root characterizations regarding the number of whorls and basal roots and for efficiency in phosphorous use.

\begin{tabular}{|c|c|c|c|c|}
\hline Code & Accession & Genotype & Seed coat color & Origin \\
\hline 1 & 33 & Jalo & Yellow & IAC \\
\hline 2 & 40 & Retinto Santa Rosa & Red & IAC \\
\hline 3 & 80 & s. 38573 & Black & IAC \\
\hline 4 & 84 & s. LEG 50600 & Black & IAC \\
\hline 5 & 89 & Venezuela 350 & Black & Venezuela \\
\hline 6 & 95 & Mulatinho- Branco & Cream colored & IAC \\
\hline 7 & 203 & Rosado-14 (Mulatinho) & IAC & 729 \\
\hline 8 & 216 & s. $91 / 71-212$ & Black & IAC \\
\hline 9 & 221 & s. $12-\mathrm{D}$ & Black & IAC \\
\hline 10 & 243 & s. 73-Vul-6621-CMG & Black & IAC \\
\hline 11 & 288 & Rosinha & Pinkish & IAC \\
\hline 12 & 325 & Rosinha -G2 & Pinkish & IAC \\
\hline 13 & 457 & Cavalo Amarelo & Yellow & IAC \\
\hline 14 & 474 & s. 73Vul-6686 & Black & IAC \\
\hline 15 & 481 & Carioca MG & Carioca & UFV \\
\hline 16 & 501 & Preto (s. 3888) & Black & IAC \\
\hline 17 & 485 & Dom Timoteo & Red & IAC \\
\hline 18 & 499 & Vermelho Graúdo (s. CF-830186) & Red & Embrapa \\
\hline 19 & 514 & Santa Rosa (s. 810510) & Red & Embrapa \\
\hline 20 & 531 & PI -310724 & Black & CIAT \\
\hline 21 & 561 & Lagartixa Precoce & Cream colored/Black & IAC \\
\hline 22 & 575 & Rai-76 & Black & IAC \\
\hline 23 & 592 & $\mathrm{Cal}-153$ & Red & IAC \\
\hline 24 & 593 & Emp-407 & Brown & Embrapa \\
\hline 25 & 613 & Diacol Calima & Cream colored & IAC \\
\hline 26 & 633 & s. RG1342CH60(MA) & Black & IAC \\
\hline 27 & 699 & Bayo & Cream colored & IAC \\
\hline 28 & 707 & IAC - Una & Black & IAC \\
\hline 29 & 712 & IAC - Bico de ouro & Cream colored & IAC \\
\hline 30 & 720 & Car* (s. L476-2) & Brown & CIAT \\
\hline 31 & 729 & Car (s. L476-4) & Cream colored & CIAT \\
\hline 32 & 742 & Car (s. 309-1) & Cream colored & CIAT \\
\hline 33 & 832 & Pérola & Carioca & Embrapa \\
\hline 34 & 844 & Pintado Rajado (Pinda) & Green & CIAT $^{1}$ \\
\hline 35 & 1139 & Rubi & Carioca & IAC \\
\hline 36 & 1180 & IAC-Alvorada & Carioca & IAC \\
\hline 37 & 1181 & IAC-Galante & Pinkish & IAC \\
\hline 38 & 1996 & BFS 39 & Red & CIAT \\
\hline 39 & 1698 & IAC- Boreal & Red & IAC \\
\hline 40 & 1703 & IAC-Jabola & Green & IAC \\
\hline 41 & 2172 & G2333 & Red & CIAT \\
\hline 42 & 1381 & DOR 364 & Brown & CIAT \\
\hline
\end{tabular}

For evaluation of the number of whorls and basal roots, 15 seeds from each genotype were germinated between two sheets of germination paper moistened with distilled water in the amount of 2.5 times the weight of the dry paper, and a completely randomized experimental design was used, with 15 replications. The rolls for germination were transferred to a B.O.D. germination chamber with a temperature of $25 \pm 3^{\circ} \mathrm{C}$. After five days, the seedlings were removed and evaluated by counting the number of whorls and basal roots.

The experiment to evaluate performance regarding $\mathrm{P}$ use was conducted in a closed hydroponic system, and a completely randomized experimental design was used, with three replications. The 42 genotypes were cultivated up to grain production. 
The seeds of the genotypes were pre-germinated in moistened germination paper and incubated at $25^{\circ} \mathrm{C}$. Single seedlings at four days of development and that had roots of around $5 \mathrm{~mm}$ in length were transferred to individual $3.5 \mathrm{~L}$ capacity pots filled with sand and grown in a hydroponic system.

The nutrient solution, containing half of the ideal $\mathrm{P}$ concentration, used for inducing $\mathrm{P}$ stress was prepared with deionized water and was composed of $143.0 \mathrm{mg} \mathrm{L}^{-1}$ of $\mathrm{N}, 132.5$ $\mathrm{mg} \mathrm{L}^{-1}$ of $\mathrm{K}, 121.0 \mathrm{mg} \mathrm{L}^{-1}$ of $\mathrm{Ca}, 25.5 \mathrm{mg} \mathrm{L}^{-1}$ of $\mathrm{Mg}, 33.0 \mathrm{mg} \mathrm{L}^{-1}$ of $\mathrm{S}, 1.81 \mathrm{mg} \mathrm{L}^{-1}$ of $\mathrm{Fe}$, $0.45 \mathrm{mg} \mathrm{L}^{-1}$ of $\mathrm{Cu}, 0.18 \mathrm{mg} \mathrm{L}^{-1}$ of $\mathrm{Zn}, 0.45 \mathrm{mg} \mathrm{L}^{-1}$ of $\mathrm{Mn}, 0.45 \mathrm{mg} \mathrm{L}^{-1}$ of $\mathrm{B}, 0.09 \mathrm{mg} \mathrm{L}^{-1}$ of Mo, $0.09 \mathrm{mg} \mathrm{L}^{-1}$ of $\mathrm{Ni}$, and $4.00 \mathrm{mg} \mathrm{L}^{-1}$ of P (Silva et al., 2014).

During the first 15 days after setting up the experiment, the plants were irrigated with half strength nutrient solution, i.e., half the total concentration to be used and then, increased to full strength. Through daily monitoring of the nutrient solution, electrical conductivity was maintained from 1.8 to $2.0 \mathrm{mS} \mathrm{cm}^{-1}$, and $\mathrm{pH}$ was maintained near 5.8 . Sowing was carried out in the autumn-winter season and the maximum average, minimum average and average temperatures in the greenhouse during cultivation were 28,16 and $22^{\circ} \mathrm{C}$, respectively.

The full flowering stage was reached at 45 days after transfer of the seedlings, at which time leaves were collected from the middle third of the plant for determination of nutrient contents. Samples consisting of $1.0 \mathrm{~g}$ of dried and ground leaf tissue were subjected to nitric-perchloric acid digestion for extraction of $\mathrm{P}, \mathrm{K}, \mathrm{Ca}, \mathrm{Mg}$, and $\mathrm{S}$. In the extracts, the contents of these nutrients were determined by atomic absorption spectrophotometry. Total $\mathrm{N}$ was determined from $0.2 \mathrm{~g}$ of leaf tissue, which was subjected to sulfuric acid digestion and then distillation by the Kjeldahl method; and $\mathrm{P}$ was determined by UV-VIS spectrophotometry (Malavolta et al., 1989).

The following evaluations were made:

Roots: root dry matter $(\mathrm{g})$, diameter $(\mathrm{mm})$, volume $\left(\mathrm{cm}^{3}\right)$, total length $(\mathrm{cm})$, and surface area, using the WinRHIZO® software.

Shoot: plant height $(\mathrm{PH})$, number of nodes per plant (NOD), days to flowering (DF).

Yield traits: number of pods per plant (NPP), number of seeds per pod (NSP), 100seed weight (100SW) in grams, and grain yield (GY) in g plant $^{-1}$.

Analysis of variance (ANOVA) was performed on the results (F test), followed by the Scott-Knott means test at 5\% probability, Pearson correlation (ggcorrplot R-package), and GGE-biplot (GGEBiplotGUI R-package) analysis.

\section{RESULTS AND DISCUSSION}

To gauge the effectiveness of induction of $\mathrm{P}$ deficiency in plants in the experiment conducted in a hydroponic system to the full flowering stage (R-6), leaf analyses of the 42 genotypes were performed. The mean $\mathrm{P}$ content in the leaf tissue of the genotypes was 2.20 $\mathrm{g} \mathrm{kg}^{-1}$, with a lower content of $1.20 \mathrm{~g} \mathrm{~kg}^{-1}$ for the genotypes Dom Timóteo and G2333 up to the highest content of $3 \mathrm{~g} \mathrm{~kg}^{-1}$ for the genotype DOR 364. This shows that growing in the nutrient solution was adequate for induction of $\mathrm{P}$ deficiency in the plants, resulting in nutrient contents in the leaf tissue below the range of the content considered adequate for $\mathrm{P}$, from 4 to $6 \mathrm{~g} \mathrm{~kg}^{-1}$ (Malavolta, 2006). The values obtained for calcium and potassium were 
within the adequate range, and for nitrogen, magnesium, and sulfur, they were a little below the adequate range (Table 2).

Table 2. Macronutrient levels in the leaf tissue of common beans $\left(\mathrm{g} \mathrm{kg}^{-1}\right)$ grown in a hydroponic system with phosphorous restriction $\left(4.00 \mathrm{mg} \mathrm{L}^{-1}\right)$.

\begin{tabular}{lllllll}
\hline Treatment & $\mathbf{N}$ & $\mathbf{P}$ & $\mathbf{K}$ & $\mathbf{C a}$ & $\mathbf{M g}$ & $\mathbf{S}$ \\
\hline Adequate & & & & $(\mathbf{g ~ k g})$ & & \\
\hline Mean & $52-54$ & $4-6$ & $15-35$ & $15-25$ & $4-8$ & $5-10$ \\
\hline * & 44.2 & 2.2 & 41.1 & 24.3 & 3.5 & 2.3 \\
\hline
\end{tabular}

*Ranges of contents considered adequate for macronutrients and mean of contents from collection of the third leaves with petiole, taken from the middle third of 30 common bean plants in the flowering stage (Malavolta, 2006).

Individual analyses of variance for the 15 traits evaluated showed a significant effect of genotypes, except with regard to root dry matter (RDM), number of seeds per pod (NSP), and 100 seed weight (100SW). The experimental coefficients of variation observed were satisfactory, ranging from 3.1 to 19.8, with good experimental accuracy (Table 3).

Table 3. Summary of analysis of variance of the agronomic traits of 42 common bean genotypes grown in a hydroponic system with $4.00 \mathrm{mg}$. $\mathrm{L}^{-1}$ of phosphorous.

\begin{tabular}{|c|c|c|c|c|c|c|c|c|c|}
\hline S.V. & D.F. & Mean square & $e^{\text {NBR }}$ & D.F. & \multicolumn{4}{|c|}{ Mean square } & $\mathbf{R D M}^{\mathbf{t}}$ \\
\hline Genotype & 41 & $6.577 * *$ & $100.197 * *$ & 41 & $955.200 *$ & $104.810 * *$ & $1.086 * *$ & $0.001^{*}$ & 0.09 \\
\hline Residue & 588 & 0.063 & 1.085 & 84 & 534.900 & 54.390 & 0.525 & 0.001 & 0.105 \\
\hline C.V. $(\%)$ & & 11.2 & 12.19 & & 18.111 & 16.203 & 13.434 & 7.633 & 13.624 \\
\hline \multirow{2}{*}{ S.V. } & \multirow{2}{*}{ D.F. } & PH & NOD & D.F. & $\mathbf{N P P}^{\mathrm{t}}$ & NSt & NSP & $100 S W^{t}$ & GY $^{\mathbf{t}}$ \\
\hline & & \multicolumn{2}{|c|}{ Mean square } & & & & & & \\
\hline Genotype & 41 & $7051^{* * *}$ & $26.231^{* *}$ & $41.930 * *$ & $1.052 * *$ & $6.683 * *$ & 0.043 & 0.593 & $0.864 * *$ \\
\hline Residue & 84 & 343.000 & 4.373 & 1.960 & 0.174 & 0.925 & 0.047 & 0.657 & 0.242 \\
\hline C.V. $(\%)$ & & 19.767 & 14.113 & 3.110 & 9.613 & 12.306 & 7.109 & 14.054 & 11.778 \\
\hline
\end{tabular}

The number of root whorls (WRL) among the genotypes ranged from 1 to 4 , with an overall mean of 2.25. The genotypes 13 (Cavalo Amarelo), 23 (Cal-153), and 39 (IACBoreal) stood out with the largest number of whorls, 4.00, 3.60, and 3.53, respectively. The accessions 5 (Venezuela 350), 6 (Mulatinho Branco), and 17 (Dom Timóteo) had only one whorl, as the lowest mean number (Supplementary 1). The number of basal roots (NBR) ranged from 4.20 to 14.84 , with an overall mean of 8.55 . The accessions 13 (Cavalo Amarelo), 21 (Lagartixa Precoce), and 31 (Car s. L476-4) had the highest mean numbers of basal roots, 14.86, 14.86, and 14.33, respectively, whereas the accessions 5 (Venezuela 350), 6 (Mulatinho Branco), and 25 (Diacol Calima) had the lowest mean values for number of basal roots, 4.26, 4.26, and 4.20, respectively (Supplementary 1). Vieira et al (2008) evaluated root traits of 19 common bean genotypes and observed that the number of whorls ranged from 1.47 to 3.07 , and the number of basal roots, from 5.67 (genotype TO) to 12.07 (cultivar Jalo MG-65). Moreover, the genotypes DOR 364 and G 2333 presented basal deep 
roots, G 2333 had abundant root hairs, a favorable trait for P acquisition, which is known to be positively correlated with total acid exudation.

Teixeira et al. (2019) also analyzed the number of whorls and basal roots of 1,000 genotypes of common beans from the germplasm bank of the Instituto Agronômico by the Generalized Mahalanobis Distance $\left(\mathrm{D}^{2}\right)$ and with the Tocher clustering method and identified seven divergence groups, considering the two root traits. The number of whorls observed also ranged from 1 to 4 among the genotypes, and the number of basal roots ranged from 3 to 16, with a correlation coefficient of $97.95 \%$ between the traits. Miguel et al. (2013) observed that accessions of wild common beans tend to have one or two whorls, while the cultivated accessions have up to five. In addition, these authors did not observe variation of the traits with $\mathrm{P}$ availability, showing that there was no plasticity in this trait in these genotypes. Nevertheless, these authors observed the importance of the greater number of whorls, which results in an increase in $\mathrm{P}$ acquisition at low concentrations of the nutrient.

According to Lynch and Brown (2001), Basu et al. (2007), Rubyo and Lynch (2007), Viera et al. (2007), and Vieira et al. (2008), the common bean root system is typical of a dicotyledonous plant, consisting of a primary root with positive gravitropism, basal roots, and adventitious roots. It can have from one to four whorls, and each whorl can have from two to four basal roots, which, together with the lateral roots that emerge from them, constitute most of the total length of the plant roots. The common bean has wide genetic variability for root traits, especially in relation to root mass, root architecture, number of basal roots, number of whorls, gravitropism of the basal roots, and number of root hairs.

According to Wissuwa (2003), the size of the root system is considered an important trait in evaluation of plants tolerant to low soil P contents. However, severe P deficiency not only limits total plant growth, but also limits root growth. To maintain satisfactory root growth rates despite low soil P contents, the capacity of developing a root system of large dimensions is extremely important. In our study, only the root dry matter (RDM) trait did not show a significant effect for the genotypes.

The mean length of the root system (RL) was $16,720.4 \mathrm{~cm}$, with an amplitude from $26,364.5 \mathrm{~cm}$ for genotype 8 (s. 91/71-212) to $10,281.1 \mathrm{~cm}$ for genotype 31 (Car s. L476-4). The Scott-Knott means test at 5\% probability clustered the genotypes into two groups -23 genotypes had the highest mean values regarding root length. Root surface area (RSA) showed significant differences among genotypes, ranging from $3,163 \mathrm{~cm}^{2}$ for genotype 16 (Preto s. 3888) to $1,056.9$ for genotype 28 (IAC-Una), with a mean of $2,052 \mathrm{~cm}^{2}$; the means test clustered the genotypes into two different groups, and it is noteworthy that 22 genotypes had mean values greater than $2,000 \mathrm{~cm}^{2}$. Shanka et al. (2018) observed that the P efficient cultivars Haramaya and Dinkinesh produced greater root length and root surface area under low $\mathrm{P}$ condition, suggesting that favorable root morphological growth inherent to these cultivars might have enabled them to better adapt to $\mathrm{P}$ deprivation.

The volume of the root system (VR) had a mean value of $20.2 \mathrm{~cm}^{3}$, and the genotypes were clustered into two groups by the means test. Genotype 8 (s. 91/71-212) had the maximum amplitude at $30.91 \mathrm{~cm}^{3}$, and genotype 28 (IAC-Una) had the minimum, at $10.14 \mathrm{~cm}^{3}$. For root diameter (RD), although the $\mathrm{F}$ test of analysis of variance was significant at 5\% probability, there was no clustering of genotypes using the Scott-Knott means test at $5 \%$, with mean values ranging from 0.424 to $0.341 \mathrm{~mm}$. The $\mathrm{F}$ test of analysis of variance was not significant for root dry matter (RDM), and there was no clustering by 
the Scott-Knott means test at $5 \%$. The overall mean was $2.12 \mathrm{~g}$, ranging from 0.956 for genotype 6 (Mulatinho Branco) to $2.822 \mathrm{~g}$ for genotype 8 (s. 91/71-212).

The identification of root traits that are important in $\mathrm{P}$ acquisition allows breeders that study the common bean crop to develop new cultivars with better yield under conditions of low soil nutrient contents. In general, the depth of the root system determines the efficiency of utilization of surface resources, such as $\mathrm{P}$, and deep resources, such as water. Lateral roots generally constitute most of the biomass of the root system.

Plant height $(\mathrm{PH})$ was clustered into five groups, using the Scott-Knott means test at $5 \%$ probability, with a mean value of $100.89 \mathrm{~cm}$. The genotypes that had the highest mean values for PH were 41 (G 2333), 17 (Dom Timóteo), and 1 (Jalo), with mean values of 242.64, 232.64, and $189.33 \mathrm{~cm}$, respectively. These genotypes have a climbing growth habit. The genotypes clustered with the lowest means had values lower than $70.00 \mathrm{~cm}$. For nodes per plant (NOD), the mean was 14.81 and, using the Scott-Knott test at 5\% probability, the genotypes were clustered into four groups, with 15 genotypes being allocated to the group with mean values higher than 16 nods.

There was a mean of 45 days from transplant of the seedlings until flowering, and this variable was clustered into five groups by the means test. The genotypes that had the lowest mean values, i.e., with an early cycle, less than 39 days, were 23 (Cal-143), 25 (Diacol Calima), 39 (IAC Boreal), 2 (Retinto Santa Rosa), and 27 (Bayo).

In relation to production components and grain yield, only the variables of number of seeds per pod and 100-seed weight did not show significant differences by the F test, without variability for selection. The trait of number of pods per plant (NPP) ranged from 4.67 to 24.00 and was clustered into four groups by the Scott-Knott test $(\mathrm{P}<0.05)$. The genotypes that were most prominent were 41 (G2333) and 35 (Rubi), both with mean values of 24.00 pods per plant. The variable of number of seeds per plant was likewise clustered into four groups by the means test, and the most prominent genotypes were 16 (Preto s.3888), 41 (G2333), 8 (s. 91/71-212), and 35 (Rubi).

The mean value regarding the number of seeds per pod (NSP) was 4.18, and the trait had variations from 2.88 for genotype 27 (Bayo) to 6.14 for genotype 16 (Preto s.3888). A significant difference among the genotypes was not observed. As for 100-seed weight (100SW), a mean of $23.35 \mathrm{~g}$ was found, without statistical differences by the F test, ranging from 13.64 for genotype 5 (Venezuela 350) to 42.66 for genotype 18 (Vermelho Graúdo).

The mean grain yield (GY) observed was $10.55 \mathrm{~g}$ plant $^{-1}$, and the genotypes were clustered by the Scott-Knott means test $(P<0.05)$ into three different groups, of which genotypes 41 (G 2333) and 35 (Rubi) stood out with the highest yields, with mean values of 23.85 and $23.39 \mathrm{~g} \mathrm{plant}^{-1}$, respectively. These genotypes also stood out in relation to the variables RL, RSA, VR, NPP, and NS. Another 13 genotypes clustered into a second group, with intermediate mean yield values, greater than $10.48 \mathrm{~g} \mathrm{plant}^{-1}$. Using the same restrictive P level, Silva et al. (2014) observed an average of $28.9 \mathrm{~g} \mathrm{plant}^{-1}$ for grain yield of 20 bean genotypes, and genotype G 2333 also stood out as efficient in P use, obtaining high productivity under low P conditions $\left(29 \mathrm{~g}\right.$ plant $\left.^{-1}\right)$.

Pearson correlation analysis (Figure 1) showed positive correlations between: A. the production components (NPP, NS and GY) with the root system traits (RL and RSA); i.e., a more vigorous root system played a fundamental role in the increase in grain yield; $\mathrm{B}$. between plant height with GY; C. between number of nodes with days to flowering, 
Negative correlations between: A. the variable of number of whorls with days to flowering, with number of nodes, and with the production components of number of pods and number of seeds; B. number of basal roots with the root traits RV, RL, RSA and with the production components GY, NNP and NS.

According to Margaret et al. (2014), common bean plants grown at low P levels tend to accumulate dry matter despite the deficiency of $\mathrm{P}$ for plant growth. Therefore, the $\mathrm{P}$ use efficiency is related to the distribution of more biomass to roots than shoots and with the change of the acquired $\mathrm{P}$ into plant biomass and grain yield, that is, reducing the $\mathrm{P}$ requirement in plant tissues.

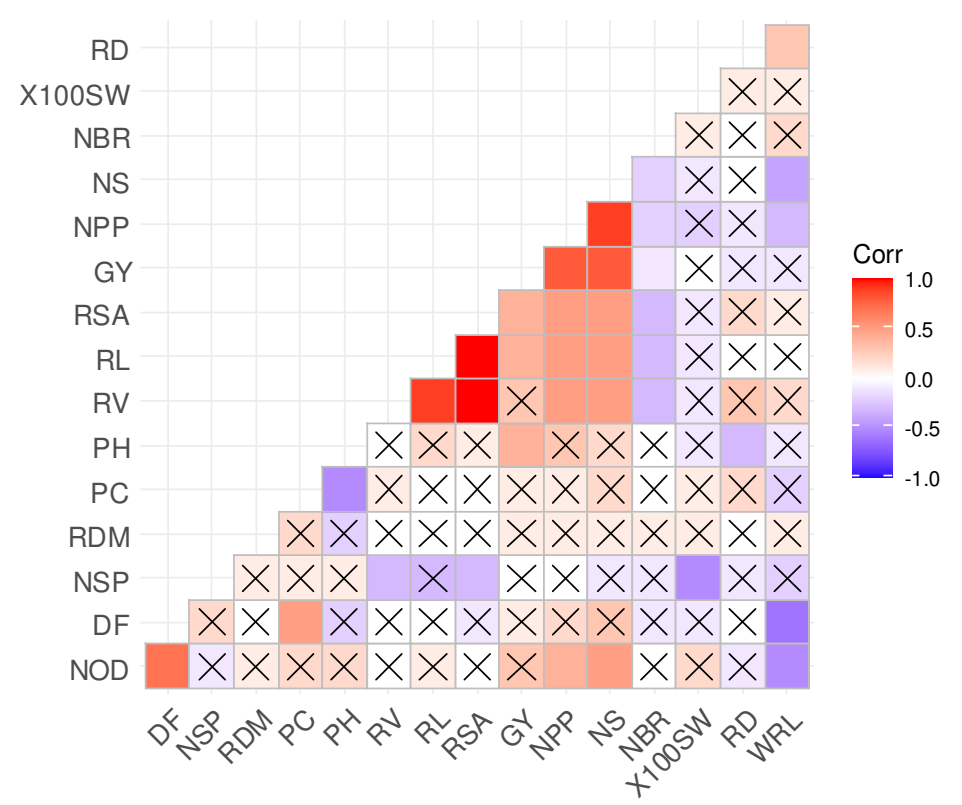

Figure 1. Pearson correlation coefficients of the 15 traits analyzed in the 42 common bean genotypes grown in a hydroponic system with the application of $4.00 \mathrm{mg} \mathrm{L}^{-1}$ of $\mathrm{P} .{ }^{\mathrm{DF}}$ Days to flowering, ${ }^{\mathrm{PH}} \mathrm{Plant}$ height, ${ }^{\mathrm{NNP}}$ Number of nodes per plant, ${ }^{\mathrm{GY}}$ Grain yield (g), ${ }^{\mathrm{NPP}}$ Number of pods per plant, ${ }^{\mathrm{NS}}$ Number of seeds, ${ }^{\mathrm{NSP}}$ Number of seeds per pod, ${ }^{100 S W}$ Hundred seed weight (g), ${ }^{\text {WRL }}$ Number of whorls, ${ }^{\mathrm{NBR}}$ Number of basal roots, ${ }^{\mathrm{RL}}$ Root length (cm), ${ }^{\mathrm{RSA}}$ Root surface area $\left(\mathrm{cm}^{2}\right),{ }^{\mathrm{RV}}$ Root volume $\left(\mathrm{cm}^{3}\right),{ }^{\mathrm{RD}}$ Root diameter $(\mathrm{mm}),{ }^{\mathrm{RDM}}$ Root dry matter $(\mathrm{g})$.

Positive relations were also found between GY, NS, and NPP with the root system variables RL, RSA, and VR through GGE-biplot analysis (Figure 2). As a cluster was formed between these traits, it was possible to select simultaneously in relation to the increase in grain yield and the production components and for the root system traits. The best performing genotypes selected were: 41 (G 2333), 35 (Rubi), 8 (s. 91/71-212), 16 (Preto s.3888), 22 (Ray 76), 26 (s. RG 1342CH60 (Ma)), 9 (s.12-D), 12 (Rosinha-G2), 7 (Rosado 14), 14 (s.73-Vul 6686), 4 (s. LEG 50600) and 20 (PI 310724).

Studying the same genotypes under drought conditions, Teixeira et al. (2019) observed a high correlation between root dry mass and grain yield, selecting 14 genotypes with good performances for both traits, and three of them also highlighted in this work under P deficiency considering the root system and grain yield, as follows: RAI 76, s.12-D, 
PI 310724. Beebe et al. (2008) concluded that selection for resistance to drought can lead to constitutional changes that are also of adaptive advantage under low $\mathrm{P}$ availability. These authors reinforce the importance of these results, as they affect the development of grains adapted to the abiotic stresses of the tropics, where drought and low soil phosphorus availability are the two main abiotic constraints to bean production.

\section{Which Won Where/What}

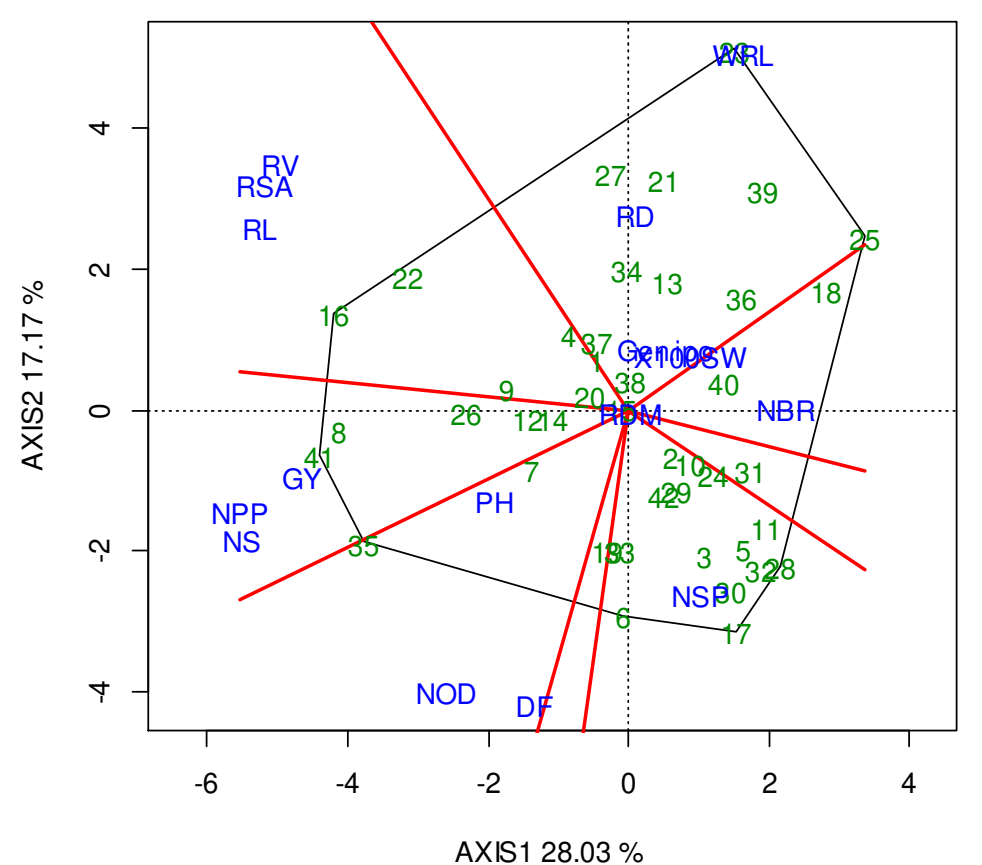

Figure 2. GGE-Biplot ("which won where") for the data of the agronomic traits of 42 common bean genotypes grown in a hydroponic system with the application of $4.00 \mathrm{mg} . \mathrm{L}^{-1}$ of $\mathrm{P} .{ }^{\text {WRL }}$ Number of whorls, ${ }^{\mathrm{NBR}}$ Number of basal roots, ${ }^{\mathrm{RL}}$ Root length $(\mathrm{cm}),{ }^{\mathrm{RSA}}$ Root surface area $\left(\mathrm{cm}^{2}\right),{ }^{\mathrm{RV}}$ Root volume $\left(\mathrm{cm}^{3}\right),{ }^{\mathrm{RD}}$ Root diameter $(\mathrm{mm}),{ }^{\mathrm{RDM}}$ Root dry matter, ${ }^{\mathrm{PH}}$ Plant height, ${ }^{\mathrm{NOD}}$ Number of nodes per plant ${ }^{\mathrm{DF}}$ Days to flowering, ${ }^{\mathrm{NPP}}$ Number of pods per plant, ${ }^{\mathrm{NS}}$ Number of seeds, ${ }^{\mathrm{NSP}}$ Number of seeds per pod, ${ }^{100 \mathrm{SW}}$ Hundred seed weight (g), GY Grain yield (g).

\section{CONCLUSIONS}

Variability was found among the genotypes for most of the variables studied, allowing clustering and selection of the genotypes;

The root traits of length, surface area, and volume were correlated with grain yield, with number of pods and seeds per plant;

The genotypes G 2333 and Rubi stood out as the highest yielding;

The following genotypes were selected based on GGE-biplot analysis through simultaneously having the best performance for grain yield, production components, and root system: 41 (G 2333), 35 (Rubi), 8 (s. 91/71-212), 16 (Preto s.3888), 22 (Ray 76), 26 (s. RG 1342CH60 (Ma)), 9 (s.12-D), 12 (Rosinha-G2), 7 (Rosado 14), 14 (s.73-Vul 6686), 4 (s. LEG 50600) and 20 (PI 310724). 


\section{ACKNOWLEDGMENTS}

The authors thanks CAPES- Coordenação de Aperfeiçoamento de Pessoal de Nível Superior and FAPESP-Fundação de Amparo à Pesquisa do Estado de São Paulo for financial support.

\section{CONFLICTS OF INTEREST}

The authors declare no conflict of interest.

\section{REFERENCES}

Basu P, Zhang YJ, Lynch JP and Brown KM (2007). Ethylene modulates genetic, positional, and nutritional regulation of root plagiogravitropism. Funct. Plant Biol. 34: 41-51.

Beebe SE, Rao IM, Cajiao C and Grajales M (2008). Selection for Drought Resistance in Common Bean Also Improves Yield in Phosphorus Limited and Favorable Environments. Crop Sci. 48: 582-592.

Beebe SE, Ochoa I, Skroch P, Nienhuis J, et al. (1995). Genetic diversity among common bean breeding lines developed for Central America. Crop Sci. 35: 1178-1183.

Ericsson T and Ingestad T (1988). Nutrition and growth of birch seedlings at varied relative phosphorus addition rates. Physiol. Plant. 227-235.

Fidelis RR, Miranda GV, Pelúzio JM and Galvão JCC. (2010). Classificação de populações de milho quanto à eficiência e resposta ao uso de fósforo. Acta Sci. 32(2): 241-246.

Hammond JP, Broadly MR and White PJ (2004). Genetic responses to phosphorus deficiency. Ann Bot. 94: 323-332.

Henry A, Rosas JC, Beaver JS and Lynch JP (2010). Multiple stress response and belowground competition in multilines of common bean (Phaseolus vulgaris L.). Field Crops Res. 117(2-3): 209-218.

Lambers HY, Shane MW, Cramer MD, Pearse SJ, et al. (2006). Root structure and functioning for efficient acquisition of phosphorus: matching morphological and physiological traits. Ann. Bot. 98: 693-713.

Liao H, Yan X, Rubio G, Beebe SE, et al. (2004). Genetic mapping of basal root gravitropism and phosphorus acquisition efficiency in common bean. Funct. Plant Biol. 31(10): 959-970.

Lynch JP and Brown KM (2001). Topsoil foraging: an architectural adaptation to low phosphorus availability. Plant Soil. 237: 225- 237.

Malavolta E (2006). Manual de nutrição mineral de plantas. São Paulo: Editora Agronômica Ceres. 2006, 638p.

Malavolta E, Vitti GC and Oliveira SA (1989). Avaliação do estado nutricional das plantas: princípios e aplicações. Piracicaba: Associação Brasileira para Pesquisa da Potassa e do Fosfato. 201p.

Margaret N, Tenywa JS, Otabbong E, Mubiru DN, et al. (2014). Development of Common Bean (Phaseolus vulgaris L.) Production under low soil phosphorus and drought in sub-saharan africa: a review. J. Sustain. Dev. 7(5): 128139.

Miguel MA, Widrig A, Vieira RF, Brown KM, et al. (2013). Basal root whorl number: a modulator of phosphorus acquisition in common bean (Phaseolus vulgaris). Ann. Bot. 112(6): 973-982.

Niu YF, Chai RS, Jin LG, Wang H, et al. (2013). Responses of root architecture development to low phosphorus availability: a review. Ann. Bot. 112: 391-408.

Olivera M, Tejera N, Iribarne C, Ocaña A, et al. (2004). Growth, nitrogen fixation and ammonium assimilation in common bean (Phaseolus vulgaris): effect of phosphorus. Physiol. Plant. 121: 498-505.

Rubio G and Lynch JP (2007). Compensation among root classes in Phaseolus vulgaris L. Plant Soil. 290: $307-321$.

Shanka D, Dechassa N, Gebeyehy and Elias E (2018). Phosphorus Use Efficiency of Common Bean Cultivars in Ethiopia. Commun. Soil Sci. Plant Anal. 49(11): 1302-1313.

Silva RJS and Vahl LC (2002). Resposta do feijoeiro à adubação fosfatada num neossolo litólico distrófico da região sul do Rio Grande do Sul. Rev. bras. Agrocienc. 8(2): 129-132.

Silva DA, Esteves JAF, Messias U, Teixeira A, et al. (2014). Efficiency in the use of phosphorus by common bean genotypes. Sci Agr. 71:3 232-239.

Singh SP, Terán H, Muñoz CG, Osorno JM, et al. (2003). Low soil fertility tolerance in landraces and improved common bean genotypes. Crop Sci. 43: 110-119.

Teixeira A, Silva DA, Gonçalves JGR, Esteves JAF, et al. (2019). Root characterization of bean genotypes (Phaseolus vulgaris) under drought stress. Genet. Mol. Res. 18(1): GMR18086.

Vance CP, Uhde-Stone C and Allan DL (2003). Phosphorus acquisition and use: critical adaptations by plants for securing a nonrenewable resource. New Phytol. 157: 423-447. 
Vieira RF, Jochua CN and Lynch JP (2007). Method for evaluation of root hairs of common bean genotypes. Pesq. agropec. bras. 42: 1365-1368.

Vieira RF, Carneiro JES and Lynch JP (2008). Root traits of common bean genotypes used in breeding programs for disease resistance. Pesq. agropec. bras. 43: 707-712

Wissuwa M (2003). How Do Plants Achieve Tolerance to Phosphorus Deficiency? Small Causes with Big Effects. Plant Physiol. 133: 1947-1958. 